\title{
The magnificent " $I$ " in business education: Evidence from Greece
}

\begin{tabular}{|r|l|}
\hline Journal: & Journal of Applied Research in Higher Education \\
\hline Manuscript ID & JARHE-02-2019-0031.R2 \\
\hline Manuscript Type: & Research Paper \\
\hline Keywords: & narcissism, business education, personality characteristics, Greece \\
\hline \multicolumn{2}{|r}{} \\
\hline
\end{tabular}




\section{The magnificent "I" in business education: Evidence from Greece}

\section{Abstract}

Purpose

The goal of this research study has been twofold. First, to examine the level of narcissism and its individual traits in students who study business, in the particular context of a regional country such as Greece and second, to test how several demographic variables are related to narcissism levels.

\section{Design/methodology/approach}

The study consists of a theoretical part on narcissism in business education and an empirical part that was based on a survey conducted with the use of a questionnaire. The analysis includes hypothesis testing and basic statistical tests.

\section{Findings}

Findings suggest that sex, study levels, years of business experience and (personal/family) income do impact specific narcissistic dimensions, which may be cause for concern both for employers and higher education providers.

\section{Research limitations/implications}

The study was conducted in a regional country, the participants were students of public higher education institutions only, and the questionnaire was selfreported, and this could lead to likely social desirability effects.

\section{Practical implications}

The investigation of narcissism in the Greek business education might be of interest to: (a) business education providers (for providing curriculum that help future managers/leaders to deploy the positive characteristics of narcissism and avoid or not to develop the negative ones) and (b) to future employers to apply more effective human resource practices, i.e. selection, training, rewarding.

\section{Originality/value}

The study at hand aimed to investigate the presence of narcissism and its individual (narcissistic) behavioral dimensions in students studying business in Greece.

Article Type: Research Paper

Keywords: Narcissism, business education, personality characteristics, Greece 


\section{Introduction}

Narcissism is theorized as a set of characteristics and behaviors of an individual that reveals various degrees of: a) passion and obsession with itself, b) interest or aloofness for understanding others' feelings, c) egocentric and relentless pursuit of personal gratification, domination and ambition through the admiration of its own personal capabilities (Kets de Vries, 2014; Campbell and Miller, 2011; Morf and Rhodewalt, 2001; Maccoby, 2000).

As a concept, narcissism is present in social personality (Foster and Campbell, 2007) and psychiatric literature (e.g. Campbell et al., 2011). By being one of the three dark sides of personality along with Machiavellianism and psychopathy (Paulhus and Williams, 2002), it is usually unveiled by an individual's extremely positive view of itself (ego), a peculiar self-regulation pattern, namely a tendency to maintain this positive view of itself at any cost and a tendency to form shallow relationships with other people (Brunell et al., 2008). According to the various degrees of narcissism present in every individual, there are two main categories: a) healthy/productive narcissism which reflects the basic human need for love and admiration and is related to age and maturity level of individuals who are presented as self-confident, having empathy and a sense of what they can truly accomplish while they may be willing to take risks and combine their passion and energy to create/innovate, and b) unhealthy narcissism that reflects a strong lack of empathy, a distorted view of personal abilities, it entails manipulating and exploiting people while aggressive and antisocial behavior may be displayed (Harrison and Clough, 2006; Maccoby, 2000; Kernberg, 1975; Kohut, 1972; Freud, 1914).

Narcissism is linked to several positive characteristics and outcomes, such as selfesteem and positive affect, extraversion and satisfaction from life (Sedikides and Campbell, 2017; Sedikides et al., 2004; Campbell et al., 2002). Narcissism is also related to charisma and vision (Rosenthal and Pittinsky, 2006), to an increased tendency for leadership (Anninos, 2018; Resick et al.,2009) and to high performance in short term creativity contexts, such as classroom context (Westerman et al., 2016; Goncalo et al., 2010). Nevertheless, narcissistic personalities can often resort to negative behaviors such as violence, aggression, white collar crime (Martinez et al., 2008; Lakey et al., 2008; Blickle et al., 2006; Luhtanen and Crocker, 2005; Campbell, et al., 2005) and morally questionable behavioral patterns, such as the use of resources to achieve personal goals and the pursuit of risky strategies (Campbell et al., 2004).

In addition, there are converging findings documenting the impact of narcissism on various organizational parameters such as leadership (Kets de Vries, 2014; Resick et al., 2009; Brunell et al., 2008; Rosenthal and Pittinsky, 2006), task performance (Wallace and Baumeister, 2002), management practices and decision making (Foster and Trimm, 2008; Chatterjee and Hambrick, 2006). The behavior of narcissistic individuals holding leadership positions in organizations impacts those organizational parameters which are preconditions for organizational excellence such as people, values and self-improvement (Anninos, 2018). It is therefore clear how this is a matter of concern not only for potential employers but also for business schools, which need to have relevant strategies and policies in place to diagnose narcissism of faculty and students, understand its causes and/or manage relevant behavioral cases. 


\section{Narcissism in business schools}

Even though the significance of intangible elements (e.g. vision, values, service) in modern times is increasing, it is believed that young individuals tend to be more passionate about themselves and rather more materialistic than older people (Stein, 2013; Westerman et al., 2012; Bergman et al., 2010; Twenge et al., 2008) and this is something that can be ascribed to both the way of their upbringing and education and the changes happening in social and cultural context (Lieberman, 2004; Nelson, 1977). A recent study by Wetzel et al., (2017) however that was conducted in the United States presents contrasting evidence and supports that narcissism has not been increased among college students. Hence, it is imperative to point out that more data and studies are needed (in different cultures and contexts) and control for more variables to verify or not the increase of narcissism in young generations (Roberts et al., 2010). The so called "Me Me Me" generation appears as rather obsessive with glory and social acceptance, lack of empathy and exaggerating demands which are based on their belief that they deserve them (sense of entitlement). This trend is particularly obvious among business education students (Robak et al., 2007). They have higher expectations for success (Campbell et al., 2006) and some narcissism related traits like materialistic orientation and overconfidence appear to have been increased in relation to the past (Pew Research Center, 2007; Morf and Rhodewalt, 2001). It is common for professors to have students who believe that they are entitled to everything; from personal attention and guidance to complaining and negotiating grades if they are different to what they expected (Turnipseed and Cohen, 2015). In some cases, students possessing high entitlement resort to threats and psychological pressures in order to get exactly what they want (Twenge and Campbell, 2009). Instead of focusing on improving themselves, this perception of their perfect "self" lead them to put the blame on the professor and his/her methods of teaching and/or evaluating.

In literature, there are several studies that investigate narcissism in business education. Most of these studies have been conducted in the US and use the Narcissistic Personality Inventory (NPI) to unveil the degree of narcissism among students. To the best of our knowledge, Carroll (1987) was the first that examined narcissism of MBA students, in order to identify the characteristics of the narcissistic individuals related to motives for affiliation, intimacy and power. Her findings suggest that there are differences between males and females regarding narcissism and that narcissism is positively correlated with the need for power and negatively with the need for intimacy (Carroll, 1987).

Twenge et al., (2008) observed increased narcissism levels in 85 samples of American college students between 1980 and 2006 by using a cross temporal meta-analysis. This means that narcissism scores (based on the NPI) are significantly correlated with year of data collection (weighted by sample size). Among the results of their study is the rise of individualistic traits like assertiveness, agency, self-esteem, and extraversion. In the same year, Trzesniewski et al., (2008) present contradictory evidence in relation to the study of Twenge et al., (2008) and reported that narcissism is not significantly changed among students, based on data between 1982-2007 at campuses of the University of California. In another study, Twenge et al., (2008b) corroborated the above findings of Trzesniewski et al., (2008) which can be justified by cultural and ethnic shifts that took place at the University of California. 
Three more studies on narcissism and more specifically on the relationship between narcissism and leadership were undertaken by Brunell et al., (2008). The first two involved psychology college students and the third managers in an executive MBA program. In the first two studies it was found that narcissism is a predictor of leader emergence and that it was positively correlated with the desire to lead and self-ratings on leadership. However, in the third study it was shown that students rated highest in narcissism were most likely to be identified as emerging leaders (Brunell et al., 2008).

Brown et al., (2010) based on the hypothesis that ethical behavior has its roots on personality characteristics, surveyed business students (by using "selfism" questions) to investigate the role of empathy or narcissism in ethical decision making. They indeed documented that empathetic and narcissistic personality traits significantly predict ethical decision making and suggested that students studying finance exhibited a statistically significant tendency for less empathy and more narcissism compared to other business students. This means that the discipline of finance appears to attract or cultivate students that have those personality characteristics which lead to less ethical decision making.

Traiser and Eighmy (2011) conducted a survey in undergraduate students studying in public and private universities and found that private university students had higher narcissism scores in comparison with students from public institutions. They moreover found a positive relationship between narcissism and family income and a negative one between narcissism and age (as individuals grow, expectations dissipate). While it is believed that students who take ethics courses tend to make more ethical decisions, this study concludes that this is something that has no impact on students' moral reasoning. Also, the connection of narcissism and entitlement becomes apparent in the Menon and Sarland (2011) study which found that exploitative attitude is a mediator in the relationship between narcissism, entitlement and academically wrong behavior.

In another relevant study, (Westerman et al., 2012) by using data from undergraduate business and psychology students at Appalachian State University, they compared the level of narcissism between students of these two disciplines and examined if narcissism influences salary and career expectations. Their findings suggest that business students are more narcissists than their psychology colleagues; narcissism does not appear to have any significant relationship with class activities and that narcissistic individuals seem to be more successful in terms of employment, salary and promotions. This finding can be explained by the fact that narcissism is related with undertaking risks and entrepreneurial intentions (Mathieu and St Jean, 2013).

Brown et al., (2013) conducted a survey with the aim to examine the level of narcissism as well as potential differences between accounting students at a public and a private institution in the Midwest US. By using the NPI, they found out that: a) accounting students have a lower level of narcissism in comparison with other business students and the general population of college students, b) there are not significant differences between state and private school students, something that contradicts Traiser and Eighmy's findings, c) there are differences between men and women regarding vanity (women score higher) and entitlement (men scored higher), d) students who hold leadership positions attain higher NPI scores. It is noted that the average NPI score of 15,75 of this study was somewhat higher than the average score for the general U.S. 
population (15.3), but below the average for MBA students (16.18) and celebrities (17.8) (Foster et al., 2003; Young and Pinsky, 2006). Accounting students appear to be less narcissistic than celebrities and MBA students on Self-sufficiency, Exhibitionism, Vanity and Entitlement, have mixed results on Authority and Exploitativeness and scored higher than both of the other groups on Superiority.

Bergman et al. (2013) studied the relationship between narcissism, materialism, and environmental ethics in undergraduate business students at an AACSB accredited business school. Their findings reassure the connection of narcissism and materialism and their relationship to low environmental ethics even though they present an indirect impact of narcissism and students` environmental ethics.

The relationship of narcissism and academic entitlement was studied by Turnipseed and Cohen (2015). The authors suggest than students' narcissism (male students score higher on dark personality traits) is indeed related to academic entitlement which is translated to several behavioral patterns such as negotiating grades, exercising psychological pressure on teaching staff and feeling invincible (Turnipseed and Cohen, 2015). If students manage to achieve what they want, it is highly likely that these behaviors will be repeated in the future.

Recently, Westerman et al., (2016) studied the congruence of faculty and students' narcissism. According to their findings students that score low on narcissism tend to struggle in classes with narcissistic professors, feeling high difficulty and considering teaching staff to be of lower status. On the contrary when there is congruence between high narcissism of both students and faculty, students perceive classes less difficult, get high grades and view professor as being of high status. Hence, student faculty narcissism fit is a key parameter in any attempt to harness narcissism in educational contexts.

The issue of narcissism in the Greek higher education context and more specifically in business education has been underdeveloped. Gkika and Sahinidis (2013) explored narcissism in undergraduate business students at a large higher education institution in Athens and found that students had higher narcissism levels than their parents. More specifically, male students scored higher on some narcissism traits like self-absorption, self-admiration, leadership/authority and superiority/arrogance while they reassured that aging reduce narcissistic traits.

The above studies are briefly presented in Table 1.

\section{Insert Table 1}

\section{The Greek context and study rationale}

It is widely known that during the last three years, Greece has been facing the worst crisis in its modern history; a multilevel and multifaceted crisis that was a direct consequence of a) the country's growth model that was adopted primarily after the restoration of democracy in 1974, b) the lack of a proper business mentality and a clear vision for the future and c) the country's specific cultural and historical developments. A combination of political, social and economic factors had contributed in developing a mentality that was incompatible for sustainable growth that gradually became apparent in many fields of life and corroded significantly the country's future 
perspectives. This led to low competitiveness, low foreign direct investments and an inherent inability to create new wealth and thus new employment opportunities.

The onset of the crisis has been followed by soaring numbers in unemployment, salaries and pensions cutbacks, rising income inequality and cost of living (Sotiropoulos, 2014). In 2013, Greek overall and youth unemployment reached record heights of $27 \%$ and $59.5 \%$ respectively. It is known that young people in Greece were more adversely hit by the crisis in comparison with other crisis-hit countries. In addition, the impact of structural inefficiencies, such as the weak higher education - labour market cooperation, the high informal employment, the underdeveloped sector of vocational education and the regional and gender disparities can be considered responsible for young people's feelings of marginalization from the economic and social life, strong eagerness to migrate for study/work in other countries (400,000 young Greeks left the country during the six year period from 2011 to 2017) and increase in the percentage of NEET individuals that live with their parents (Kraatz, 2015).

In such a social and economic context someone might expect low narcissism levels, perhaps lower than those recorded in other countries. So, several questions arise, such as: Do the limitations in satisfying materialistic needs impact narcissism? Are the young peoples (especially those studying business) ambitions and overconfidence crumbled and what implications does this have for future growth?

Hence, the rationale for this study and based on the analysis of relevant literature was to examine the level of narcissism in business students of a regional country hit by a severe crisis, possible differentiations among the three higher education levels (undergraduate, postgraduate, doctoral) and factors that might account for potential differences in narcissism scores. These parameters have been underdeveloped in relevant literature.

\section{Research Hypotheses and Method}

The goal of this research study has been twofold. First, to examine the level of narcissism and its individual traits in students who study business, in the particular context of a regional country such as Greece and second, to test how several demographic variables are related to narcissism levels. The investigation of narcissism in the Greek business education might be of interest to: (a) business education providers (for providing curriculum that help future managers/leaders to deploy the positive characteristics of narcissism and avoid or not to develop the negative ones) and (b) to future employers to apply more effective human resource practices, i.e. selection, training, rewarding.

In order to address the goal of the study at hand, the quantitative methodology was used. Hence, the investigation of the first part of this study`s goal (regarding the level of narcissism and its inherent dimensions) was achieved through the calculation of the participants scores in the NPI questionnaire. The second part of the goal was examined through the development and testing of the following hypotheses:

- H1. There are no statistically significant differences between men and women studying business for individual narcissism traits or categories of narcissism. 
- H2. There are no statistically significant differences between undergraduate, postgraduate and doctoral students of public business schools for individual narcissism traits or categories of narcissism.

- H3. There are no statistically significant differences among students with various levels of business experience regarding individual narcissism traits or categories of narcissism.

- H4. Career objectives do not statistically significant impact the individual narcissism traits or categories of narcissism.

- H5. The level of gross individual income does not statistically significant impact the individual narcissism traits or categories of narcissism.

- H6. The level of gross family income does not statistically significant impact the individual narcissism traits or categories of narcissism.

\subsection{Research design and sample}

The survey has been conducted electronically. Third and fourth year students, full time and part time MBA's and doctoral students in business administration, of the two largest business schools in Greece were the sample of this research study. These schools are the top two in Greece, attract students who satisfy the highest requirements and run undergraduate and postgraduate programs according to international standards.

Since the first use of the term narcissism by Ellis in 1898, there have been many attempts to conceptualize and devise a measurement scale for narcissism both as a taxonomy variable and as a distinct construct. Raskin and Terry (1988) presented an overview of these scales. Raskin and Hall in 1979 developed the NPI (Narcissistic Personality Inventory) which was further refined to its current form nine years later by Raskin and Terry. Other forms of the same instrument were developed by Emmons (1984,1987); Ames et al., 2006; Svindseth et al., 2009 and Gentile et al., 2013.

While there have been many and more recent attempts to devise a measurement scale for narcissism (e.g. Konrath et al., 2014; Glover et al., 2012; Pincus et al., 2009), the NPI is considered as the most frequently operationalization attempt of Narcissism for normal populations (Konrath et al., 2014; Del Rosario and White, 2005) and is attaining adequate validity and reliability (Rhodewalt and Morf, 1995; Raskin and Terry, 1988).

Therefore, in order to conduct this study, a two-part questionnaire was designed and used. The first part included the Narcissistic Personality Inventory (NPI-40) in English. It consists of 40 paired statements (which are divided into seven dimensions, namely authority -8 items, entitlement -6 items, exhibitionism -7 items, exploitativeness -5 items, self-sufficiency -6 items, superiority -5 items, and vanity -3 items) and respondents are asked to select the answer that matches their feelings and beliefs. Their responses are then summed (the highest the score the highest the narcissistic personality).

The Cronbach's coefficient (a) for our sample was 0.81 . The relevant values for each specific dimension have been Authority (0.65), Self Sufficiency (0.48), Superiority (0.55), Exhibitionism (0.60), Vanity (0.68), Entitlement (0.42), Exploitativeness (0.54). 
In 2018, Miller et al. published a meta-analysis of coefficient alpha scores on the NPI, in which they included Raskin's and colleagues' range of alpha by individual NPI scale. The unweighted alpha scores for a) authority range from 0.53 to $0.90, b)$ exhibitionism range from 0.49 to $0.86, \mathrm{c}$ ) superiority range from 0.41 to 0.84 , d) entitlement range from 0.31 to 0.91 , e) exploitativeness range from 0.30 to 0.86 , f) self-sufficiency range from 0.30 to 0.68 and g) vanity range from 0.50 to 0.90 .

The second self-administrated part asked for some personal and demographic data of respondents which helped us testing our research hypotheses.

The questionnaire including a cover letter explaining the purpose and significance of the study was emailed. Participants were assured of confidentiality and anonymity. For those individuals that did not reply promptly, an oral announcement was made in class followed by a reminding email. The survey was carried out between February and July of 2017, in two phases. More specifically, the first pilot phase took place in February and the second (data collection phase) took place from March to July. The pilot testing was conducted in a random sample of 50 (undergraduate and postgraduate) students to examine survey wording (possible vague terms) and reactions (potential feelings of discomfort), comprehensiveness of instructions and time needed for filling out the questionnaire.

From a sample of 350 individuals, 321 completed the questionnaire with accuracy, thus attaining an overall responsiveness rate of $92 \%$.

The analysis of data with SPSS (v24) includes basic descriptive statistics as well as normality, parametric and non-parametric initial and post hoc statistical tests.

\section{Results and discussion}

A total of 321 individuals $(98.8 \%, n=317$ of Greek origin and $1.2 \%, n=4$ of Cypriot, Albanian and Bulgarian origin) at the two largest Greek business schools participated in this study. The sex composition was $41.7 \%$ male $(n=134)$ and $58.3 \%$ female $(n=187)$. Regarding the level and type of participants' studies $37.4 \%(n=120)$ were junior $\left(3^{\text {rd }}\right.$ year) and senior $\left(4^{\text {th }}\right.$ year) students, $23.7 \%(n=76)$ were Full Time MBA students, $31.2 \%$ were Part Time MBA students $(n=100)$, and $7.8 \%(n=25)$ were doctoral candidates in Business Administration.

Table 2 provides an overview of means, standard deviations for the NPI and its individual dimensions by sex and level of study. Scores on the NPI scale may range from 0 to 40 with higher scores showing increased narcissism. The overall mean NPI score in our study was 15.63 . The minimum and maximum value on each individual narcissistic dimension are presented inside the parentheses (Table 2, first line).

\section{Insert Table 2}

According to Table 2, male participants seem to score slightly higher than female on the NPI and on every individual narcissistic dimension with the exception for vanity in which female participants score higher. When participants are classified by level of study, full time postgraduate students score higher on NPI, authority, self-sufficiency, exhibitionism, exploitativeness, vanity and entitlement than undergraduate, part time postgraduate and doctoral students. Doctoral students though score higher on superiority possibly due to their increased reference power. The fact that full time 
postgraduate students attain higher scores can be explained by the fact that they are in the beginning of their career (they have less years of business experience) and their expectations and ambitions are high.

Since an assessment of the normality of data is a prerequisite for many statistical tests, both Shapiro Wilks and Kolmogorov Smirnov (with Lilliefors significant correction) tests were conducted and a visual inspection of histograms, QQ plots and boxplots was made. In those cases that normality was violated non-parametric statistical tests were run while parametric tests were conducted when normality of data was present. A brief overview of hypotheses testing results appears in Table 3

\section{Insert Table 3}

Regarding the testing of the $1^{\text {st }}$ research hypothesis, it was shown that NPI as well as individual NPI dimensions scores are not approximately normally distributed across both groups of the independent variable (SEX). Hence, the use of non-parametric statistical methods was decided to identify potential statistically significant differences between groups. After checking the assumptions for Mann Whitney tests, (1) histograms: the two distributions had a similar pattern, hence the medians can be used to summarize the differences between groups (2) independence of groups and (3) continuous dependent variable, the test was conducted to determine whether there was a difference in the NPI scores between male and female participants. Results from that analysis indicated that there was not a statistically significant difference between sex groups even though mean NPI scores were higher in male than females (Mann-Whitney $\mathrm{U}=11113.5 ; \mathrm{Z}=-1,729 ; \mathrm{p}=0.084)$. The presence of higher narcissism levels in men has also been recorded by Carroll (1987) and Traiser and Eighmy (2011).

The same procedure was applied in the case of the 7 individual NPI dimensions. There is a statistically significant difference regarding Authority (Mann Whitney $U=9668.5$; $Z=-3.53 ; p=.000$ ), Self Sufficiency (Mann Whitney $U=10403.5 ; Z=-2.66 ; p=.008$ ) and Vanity (Mann Whitney $U=9840.5 ; Z=-3.4 ; p=.001$ ) between male and female. Male students attained higher scores in Authority and Self Sufficiency while female students reported higher vanity scores. The effect sizes for this analysis $(d=0.2 ; 0.15 ; 0.19)$ were found not to exceed Cohen's (1988) convention for a moderate effect $(\mathrm{d}=0.3)$. This finding (regarding vanity of female participants) was also present in Brown et al., (2013) study. Male participants also reported higher entitlement scores than female (though not at a statistically significant degree).

Regarding the 2nd research hypothesis, there was not a statistically significant difference in NPI scores for the 4 study levels (ANOVA F $(3,317)=1.615 \mathrm{p}=0.186$ ). To check the $2^{\text {nd }}$ hypothesis regarding individual narcissistic traits and after checking for normality, a Kruskal-Wallis $\mathrm{H}$ test showed that there was a statistically significant difference between students of different study levels regarding:

a) Authority. In order to investigate which groups differ significantly, a series of post hoc Mann Whitney U tests were performed. Mann-Whitney U value was found to be statistically significant $U=3305.5(Z=-3.278), p=0.001$, between the undergraduate and full time postgraduate student groups. Full time postgraduate students scored higher in authority. This difference according to Cohen (1988) appears small to moderate ( $\mathrm{r}=$ $0.23)$. 
b) Exploitativeness. After conducting post hoc Mann Whitney tests between study levels, it was found that Mann Whitney $U$ value was statistically significant $U=3098.5$ $(\mathrm{Z}=-2.145), \mathrm{p}=0.032$ between full time postgraduate students and part time postgraduate students. Full time postgraduate students reported higher scores regarding exploitativeness. This difference according to Cohen (1988) appears small $(\mathrm{r}=0.16)$. In addition, a statistically significant Mann Whitney $U$ value $U=689(Z=-2.108), p=0.035$ was found between full time postgraduate students and doctoral students. Again, full time postgraduate students scored higher than doctoral students. This difference according to Cohen (1988) appears small to moderate $(\mathrm{r}=0.21)$.

With regard to the $3^{\text {rd }}$ hypothesis, a Kruskal-Wallis $\mathrm{H}$ test showed that there was not a statistically significant difference regarding NPI scores between those students that had various levels of business experience (Kruskal Wallis $\chi^{2}(3)=2.065, p=0.559$ ). Additional Kruskal Wallis tests were performed for individual NPI dimensions. Results revealed that there were statistically significant differences in a) authority,b) selfsufficiency c) exploitativeness and d) vanity. In order to investigate which groups differ significantly, a series of post hoc Mann Whitney U tests were performed.

a)Authority:Mann Whitney $U$ value was statistically significant $U=1442.5(Z=-2.288)$, $\mathrm{p}=0.022$ between 1) those who do not have business experience and those that have only up to 1 year- This difference according to Cohen (1988) appears small to moderate $(\mathrm{r}=0.21), 2) \mathrm{U}=2457.5(\mathrm{Z}=-2.817), \mathrm{p}=0.005$ those who do not have business experience at all and those who have business experience up to 5 years (small to moderate effect $r=0.22)$ and 3) $U=2143(Z=-2.873), p=0.004$ those who do not have business experience at all and those who have business experience for more than 6 years small to moderate effect $r=0.23$ ). In all three cases, students with no business experience scored lower.

b)Self-sufficiency:Mann Whitney $U$ value was statistically significant $U=2033.0$ ( $Z=-$ 2.913), $\mathrm{p}=0.004$ between those who have up to 1 year business experience and those who have more than 6 years with an almost moderate effect $(\mathrm{r}=0.24)$. Participants with more than 6 years of business experience scored higher on self-sufficiency.

c)Exploitativeness:Mann Whitney $U$ value was statistically significant $U=2193$ ( $Z=-$ 2.732), $p=0.006$ between those who do not have business experience and those who have more than 6 with an almost moderate effect $(\mathrm{r}=0.22)$. Mann Whitney U value was statistically significant $U=3682.00(Z=-3.057), p=0.002$ between those who have 2-5year business experience and those who have more than 6 with an almost moderate effect $(\mathrm{r}=0.22)$. In both cases, students with less years of business experience scored higher on exploitativeness.

d)Vanity:Mann Whitney $U$ value was statistically significant $U=1320.5$ ( $Z=-2.992)$, $\mathrm{p}=0.003$ between those who do not have business experience and those who have up to 1 year with an almost moderate effect $(\mathrm{r}=0.27)$. Mann Whitney $\mathrm{U}$ value was statistically significant $U=2599.0(Z=-2.405), p=0.016$ between those who do not have business experience and those who have 2-5 years of business experience with a small to moderate effect $(r=0.19)$. Mann Whitney $U$ value was statistically significant $U=$ $1840.5(\mathrm{Z}=-3.685), \mathrm{p}=0.000$ between those who do have up to 1 year of business experience and more than 6 years business experience with a moderate effect $(r=0.3)$. Mann Whitney $U$ value was statistically significant $U=3641.5(Z=-3.200), p=0.001$ between those who do have 2 to 5 years of business experience-and more than 6 years 
business experience with a small to moderate effect $(r=0.23)$. Vanity seems to decrease as years of business experience increases and this is something particularly obvious in the last two cases.

Regarding hypothesis H4, a Kruskal-Wallis H test (Table 4) showed that there was not a statistically significant difference regarding NPI scores between groups (Kruskal Wallis $\chi^{2}(9)=14.472, p=0.106$ ). While there are findings relating narcissism and entrepreneurship (e.g. Mathieu and St Jean, 2013), we have not been able to find any statistically significant differences between those students that stated "the opening of their own company" as their career plan and other students with different career plans. However, we did find that there are statistically significant differences between groups regarding the trait of superiority (Kruskal Wallis $\chi^{2}(9)=17.018, p=0.048$ ).

\section{Insert Table 4}

Again, after executing a series of post hoc Mann Whitney U Test, statistically significant differences in superiority were found between those that aspire to be employed in the public sector and those students who are ambitious to work for a foreign $\mathrm{MNC}(\mathrm{U}=234, \mathrm{Z}=-2.267, \mathrm{p}=0.023)$. More specifically, results of the analysis showed that students who are planning to work for a foreign MNC have higher sense of superiority than those who plan to be employed in the public sector. This sense of superiority is also prevalent when comparing the former group and those who just want i) to work for any private sector company $(U=1723, z=-2.027, p=0.043)$, ii) to continue studying $(\mathrm{U}=7485.5, \mathrm{z}=-2.992, \mathrm{p}=0.003$, iii) to continue in the present company $(\mathrm{U}=1131.5, \mathrm{z}=-2.136, \mathrm{p}=0.033)$. It was also found that there is a statistically significant difference between students that want to change company and those who would like to change profession $(U=31, Z=-2.098, p=0.036)$ that reported a higher sense of superiority as well.

Regarding research hypothesis $\mathrm{H} 5$, an analysis of variance showed that there were no statistically significant differences between personal income group means (ANOVA F $(5,292)=0.683, p=.637)$. However, since the normality hypothesis was not sustained in the case of individual NPI dimensions across all personal income groups, the use of non-parametric statistical methods was decided to identify potential statistically significant differences between groups. A Kruskal-Wallis H test showed that there was a statistically significant difference only regarding vanity scores between the various income scores. In order to investigate which groups, differ significantly, a series of post hoc Mann Whitney U tests were performed. Table 5 presents the statistically significant Mann Whitney U values.

\section{Insert Table 5}

The above table also shows that in most of the above cases lower personal income groups is related to higher vanity. While controversial, these results can be explained by the fact that vanity (as a trait of over exposing personal positive self-view and under emphasizing negative perceptions) offer excuses for personal failures, overestimations of efficacy, intelligence and excessive physical view that might compensate for lower income levels.

The $6^{\text {th }}$ hypothesis was also investigated, after checking for normality NPI as well as individual NPI dimensions scores. It was found that dependent variables are not approximately normally distributed across all groups of the independent variable (family income). Hence, the use of non-parametric statistical methods was decided 
again to identify potential statistically significant differences between groups. A Kruskal-Wallis $\mathrm{H}$ test showed that there was a statistically significant difference regarding NPI scores between family income groups (Kruskal Wallis $\chi^{2}(4)=$ $16.277, \mathrm{p}=0.003)$.

\section{Insert Table 6}

Our findings show that on the four cases appeared in Table 6, students with higher family income tend to score higher regarding NPI. This finding agrees with previous research results (e.g. Traiser and Eighmy, 2011).

A similar procedure was undertaken for the case of individual NPI dimensions. A Kruskal-Wallis $\mathrm{H}$ test showed that there were statistically significant difference regarding authority, superiority, exhibitionism and entitlement among family income groups. In order to investigate which groups differ significantly, a series of post hoc Mann Whitney U tests were performed. Table 7 presents the statistically significant Mann Whitney U values.

\section{Insert Table 7}

Table 7 shows that students whose family income does not exceed $€ 20,000$ euros have lower authority scores in comparison with those students that come from a family with high income (€90,000 euros).

Authority (in the context of narcissism) refers to skills of leadership and ambitions for leading and gaining power. Narcissistic individuals who are mentally framed in their own mirrors of personal omnipotence consider themselves as having absolute authority. This characteristic is also related to superiority, which in our study, is higher in student groups with high family income ( $€ 70,000-€ 90,000)$ than student groups with lower family incomes. It is common that people reporting higher superiority to bloat about their own successes, think they are special, like receiving complements by other people and look down to all those they consider as being less accomplished.

Exhibitionism seems to be higher amongst students whose family income ranges from medium to high (€40,000-€90,000). It translates to a tendency for being to the center of attention and showing off.

Entitlement is getting higher as students family income is getting bigger. Our findings suggest that students with low family income (up to $€ 20,000$ ) have lower entitlement scores than students with medium and high family income (€40,000-€90,000). Entitlement in the context of narcissism is translated to personal beliefs of deserving favorable outcomes in any case.

\section{Conclusions}

The results support the view that the overall level of narcissism, in our sample of business students, does not differ from similar results reported in literature, in countries like the US and Canada. This might be attributed to the fact that Greek business schools` curriculum and academic staff are mostly affected by the Anglo-Saxonic school of business thought. It is important to note that such similarity is not even affected as one would expect by the economic crisis in Greece (high unemployment, rising income inequalities, salaries cutbacks, etc.). To the best of our knowledge there is no study investigating the narcissism of business students during economic crisis. 
A higher overall score in narcissism is present in male participants in comparison with female participants, though not statistically significant. This is also true for all individual NPI dimensions but one (vanity). Among the 4 study level groups, there was not a statistically significant difference in NPI scores, however full time MBA students seem to have a stronger sense of authority than undergraduate students and scored higher on exploitativeness than part time and doctoral students.

More years of business experience lead to higher authority and self-sufficiency scores but to lower exploitativeness and vanity scores, which sounds logical as maturity (at work) grows. Even though in literature it is reported that students-entrepreneurs are more narcissists than other vocational groups, higher narcissism was not reported among the students of our sample with entrepreneurial intent. Perhaps, this could be related with the timing of this research, in which low aspirations and pessimism due to the harsh economic conditions, in combination with bureaucratic procedures that have been impeding the flourish of entrepreneurship in Greece, have somehow crumbled motivation for new ventures, youngsters' self-confidence and personal well-being.

Higher vanity scores were noted in those cases with lower personal income, while students that come from families with high income score higher on narcissism (something which support similar findings in literature) and on authority, superiority, exhibitionism and entitlement.

\section{Implications}

Previous research (Westerman et al., 2012; Bergman et al., 2010; Twenge et al., 2008; Blickle et al., 2006; Campbell et al., 2004) has shown that (a) college students have become increasingly narcissistic, (b) business schools seem to attract more narcissistic students.

The testing of our research hypothesis suggests that individual NPI dimensions (such as authority, vanity, self - sufficiency, exploitativeness, entitlement) are associated with sex, age, study level and income. These findings call of attention to be paid, by business schools and employers.

Business schools constitute learning societies where character molding is taking place. They should neither underestimate character molding (teach/encourage/facilitate the correct ways to gain virtues) of students nor the consequences of possible (unproductive) narcissism to students, faculty, potential employers and society. For example, there are indeed cases in which students protest and claim higher grades (than those achieved during exams) and when they fail to get what they want, they sometimes insult faculty or raise issues of merit and injustice in the grading process. If these situations are not addressed by institutions with the help of suitable policies and practices, it is highly likely that they will be repeated not only in the educational context but also (and possibly combined with power) in the workplace and be translated to irrational decisions and managerial misbehaviors. In an era of required teamwork, participative decision making, interpersonal skills graduates (as future employees) with high levels of narcissism may be problematic resources for business success, as they are associated with counter-productive behaviors.

In literature, there are several practices that can be adopted. Practices aiming to reduce narcissism among business schools such as a strong responsible management orientation (e.g. PRME signatories), the inclusion of "soft" courses in curriculum, the 
provision of opportunities for service learning during internships must be employed. Of course, such practices would be of low value unless collaborative learning, teamworking, regular and personalized performance feedback and guidance, role-playing and simulations are adopted by the faculty in their teaching methodology portfolio (Bergman et al., 2010). These practices enable students view situations from multiple perspectives at the same time, to develop empathy and sensitivity but not in the expense of limiting initiatives or encouraging risk taking or innovative thinking (through business ideas` competitions, company projects etc.). Of course, it must be noted that behavioral modelling by academic staff is crucial for harnessing students unproductive narcissism. In order to be successful on that, they need to be supported by acquiring relevant knowledge and skills.

Companies on the other hand, as prospective employers, should shift their focus of selection from grades and problem-solving abilities to character issues (Crossan et al., 2013) of their potential employee. While charisma, vision, creativity and risk taking may be among the positive dimensions of narcissism, it is supported that unproductive narcissism may endanger a company`s journey to excellence through its impact on people, self-improvement, customer orientation, values, decision making and performance (Anninos, 2018). Through the use of psychometric tests and interviews they are expected to be able to diagnose narcissistic individuals during selection processes but also diagnose and eliminate companywide problematic situations through appropriate mechanisms and policies (e.g. obligatory seminars for and discussions with highly ranked executives about self-awareness and the ability to diagnose personal weaknesses, utilization of employee evaluation data, careful fact and behavior based selection of executives for promotion, development of emergency succession plans).

\section{Further research issues}

A comparative study in countries hit by economic crisis would be of interest to support or reject our findings.

Research can be replicated in a larger sample of public and private business schools to unveil potential differences in NPI and NPI dimensions' scores. Comparative studies can also be conducted in other (non-western) cultures. One more comparative study could be conducted in business schools globally that are either accredited or they have adopted the Principles for Responsible Management, to investigate whether their strong orientation to ethics and sustainability and broader business education perspective harnesses unhealthy narcissism and/or cultivates the positive characteristics of narcissism.

\section{Limitations}

Though the study provides useful insights, it has some limitations. First, it was conducted in a regional country, second the participants were students of public higher education institutions only, third the questionnaire was self-reported, and this could lead to likely social desirability effects. So, caution must be exercised in generalizing the findings to public and private business schools as well as to countries with different context and culture. 


\section{References}

Ames, D.P., Rose, P., and Anderson, C.P.(2006), The NPI-16 as a short measure of narcissism, Journal of Research in Personality, Vol.40 No. 4, pp.440-450.

Anninos, L. (2018), "Narcissist business leaders as heralds of the self-proclaimed excellence", International Journal of Quality and Service Sciences, Vol. 10 No. 1, pp. 49-60.

Bergman, J. Z., Westerman, J. W., Bergman, S. M., Westerman, J. and Daly, J.P. (2013), "Narcissism, materialism, and environmental ethics in business students", Journal of Management Education, Vol 38 No 4, pp. 489-510.

Bergman, J. Z., Westerman, J. W. and Daly, J.P. (2010), "Narcissism in management education", Academy of Management Learning and Education, Vol. 9 No. 1, pp. 119131.

Blickle, G., Schlegel, A., Fassbender, P. and Klein, U. (2006), "Some personality correlates of business white collar crime", Applied Psychology: An International Review, Vol. 55 No. 2, pp. 220-233.

Brown, J., Akers, M. and Giacomino, D. (2013), "Narcissism and accounting majors", American Journal of Business Education, Vol. 6 No. 3, pp. 375-384.

Brown, T. A., Sautter, J.A., Littvay, L., Soutter, A.C., Bearnes, B. (2010), “Ethics and personality: Empathy and narcissism as moderators of ethical decision making in business students", Journal of Education for Business, Vol. 85 No 4, pp. 203-208.

Brunell, A. B., Gentry, W. A., Campbell, W. K., Hoffman, B. J., Kuhnert, K. W., Demarree, K. G. (2008), "Leader emergence: The case of the narcissistic leader", Personality and Social Psychology Bulletin, Vol. 34 No. 12, pp. 1663-1676.

Campbell, W. K. and Miller, J. (2011), The handbook of narcissism and narcissistic personality disorder, John Wiley and Sons, New Jersey.

Campbell, W. K., Goodie, A. S. and Foster, J. D. (2004), "Narcissism, overconfidence, and risk attitude", Journal of Behavioral Decision Making, Vol. 17 No. 4, pp. 297-311.

Campbell, W. K., Brunell, A. and Finkel, E. (2006), "Narcissism, interpersonal regulation, and romantic relationships: An agency model approach", in Vohs, K. and Finkel, E. (Eds.), Self and relationships: Connecting intrapersonal and interpersonal processes, Guilford Press, New York, pp.57-83.

Campbell, W., Bush, C., Brunell, A. and Shelton, J. (2005), "Understanding the social costs of narcissism: The case of tragedy of the commons", Personality and Social Psychology Bulletin, Vol. 31 No. 10, pp. 1358-1368.

Campbell, W., Hoffman, B., Campbell, S. and Marchisio, G. (2011), "Narcissism in organizational contexts", Human Resource Management Review, Vol. 21 No. 4, pp. 268-284.

Campbell, W., Rudich, E. and Sedikides, C. (2002), "Narcissism, self-esteem and the positivity of self-views: Two portraits of self-love", Personality and Social Psychology Bulletin, Vol. 28 No. 3, pp. 358-368. 
Carroll, L. (1987), "A study of narcissism, affiliation, intimacy and power motives among students in business administration", Psychological Reports, Vol. 61, pp. 355358.

Chatterjee, A. and Hambrick, D. (2006), "It's All about Me: Narcissistic Chief Executive Officers and Their Effects on Company Strategy and Performance", Administrative Science Quarterly, Vol. 52 No. 3, pp. 351-386.

Crossan, M., Mazutis, D., Seijts, G. and Gandz, J. (2013), "Developing leadership character in business programs", Academy of Management Learning and Education, Vol 12 No. 2, pp. 285-305.

Del Rosario, P. and White, R. (2005), "The Narcissistic Personality Inventory: Testretest stability and internal consistency", Personality and Individual Differences, Vol. 39 No. 6, pp. 1075-1081.

Ellis, H. (1898), “Auto-erotism: A psychological study”, The Alienist and Neurologist, Vol.19, pp. 260-299.

Emmons, R. A. (1984), "Factor analysis and construct validity of the Narcissistic Personality Inventory", Journal of Personality Assessment, Vol.84 No.3, pp.291-300.

Emmons, R. A. (1987), "Narcissism: Theory and measurement”, Journal of Personality and Social Psychology, Vol. 52 No.1, pp.11-17.

Foster, J. and Campbell, W. K. (2007), "Are there such things as "Narcissists" in social psychology? A taxometric analysis of the Narcissistic Personality Inventory", Personality and Individual Differences, Vol. 43 No. 6, pp. 1321-1332.

Foster, J. and Trimm, R. (2008), "On being eager and uninhibited: Narcissism and approach avoidance motivation", Personality and Social Psychology Bulletin, Vol. 34 No. 7, pp. 1004-1017.

Freud, S. (1914), Zur Einführung des Narzißmus, Internationaler Psychoanalytischer Verlag, Berlin.

Gentile, B., Miller, J.D., Hoffman, B.J., Reidy, D.E., Zeichner, A., and Campbell, W.K.(2013), „A test of two brief measures of grandiose narcissism: The Narcissistic Personality Inventory 13 and the Narcissistic Personality Inventory 16", Psychological Assessment, Vol. 25 No. 4, pp.112-1136.

Gkika, E. C. \& Sahinidis, A. G. (2013), "Individual differences in narcissistic behavior between Generation Me and their parents", in Proceedings of the 1st International Conference on Computer Supported Education (COSUE '13), the 1st International Conference on Child \& Adolescent Education (CHADE '13) and the 1st International Conference on Perpetual Education (CPED '13), WSEAS, Vouliagmeni, pp.120-125.

Glover N, Miller JD, Lynam DR, Crego C, Widiger TA. (2012), "The Five-Factor Narcissism Inventory: A Five-Factor measure of narcissistic personality traits", Journal of Personality Assessment, Vol. 94 No.5, pp. 500-512.

Goncalo, J., Flynn, F. and Kim, S. (2010), "Are two narcissists better than one? The link between narcissism, perceived narcissism and creative performance", Personality and Social Psychology Bulletin, Vol. 36 No. 11, pp. 1484-1495. 
Harrison, J. and Clough, M. (2006), "Characteristics of "state of the art" leaders: Productive narcissism versus emotional intelligence and Level 5 capabilities", The Social Science Journal, Vol. 43 No. 2, pp. 287-292.

Kernberg, O. (1975), Borderline conditions and pathological narcissism, Jason Aronson, New York.

Kets de Vries, M. (2014), "Coaching the toxic leader", Harvard Business Review, Vol. 92 No. 4, pp. 100-109.

Kohut, H. (1972), “Thoughts on narcissism and narcissistic rage", The Psychoanalytic Study of the Child, Vol. 27, pp. 360-400.

Konrath, S., Meier, B.P., and Bushman, B.J. (2014). Development and validation of the Single Item Narcissism Scale SINS, PLoS One, Vol. 9 No. 8, e 103469.

Kraatz, S. (2015), Youth unemployment in Greece: Situation before the government change, Policy Department A: Economic and Scientific Policy, European Parliament,PE. 542220

Lakey, C., Rose, P., Campbell, W. and Goodie, A. (2008), "Probing the link between narcissism and gambling: The mediating role of judgment and decision-making biases", Journal of Behavioral Decision Making, Vol. 21 No. 2, pp.113-137

Lieberman, A. (2004), "The narcissistic personality disorder", in Masterson, J. and Lieberman, A. (Eds.), A therapist's guide to the personality disorders: The masterson approach, AZ: Zeig, Tucker and Theisen Inc, Phoenix, pp. 73-90.

Luhtanen, R. and Crocker, J. (2005), “Alcohol use in college students: Effects of level of self-esteem, narcissism and contingencies of self-worth", Psychology of Addictive Behaviors, Vol. 19 No. 1, pp. 99-103.

Maccoby, M. (2000), "Narcissistic leaders: The inevitable pros, the inevitable cons", Harvard Business Review, Vol. 78 No. 1, pp. 68-77.

Martinez, M., Zeichner, A., Reidy, D. and Miller, J. (2008), "Narcissism and displaced aggression: Effects of positive, negative, and delayed feedback", Personality and Individual Differences, Vol. 44 No. 1, pp. 140-149.

Mathieu, C. and St Jean, E. (2013), "Entrepreneurial personality: The role of narcissism", Personality and Individual Differences, Vol. 55 No. 5, pp. 527-531.

Menon, M. and Sharland, A. (2011), "Narcissism, exploitative attitudes and academic dishonesty: An exploratory investigation of reality versus myth", Journal of Education for Business, Vol. 86 No. 1, pp. 50-55.

Miller BK, Nicols KM, Clark S, Daniels A, Grant W (2018), "Meta-analysis of coefficient alpha for scores on the Narcissistic Personality Inventory", PLoS ONE, Vol. 13 No. 12: e0208331

Morf, C. and Rhodewalt, F. (2001), "Expanding the paradoxes of narcissism: A dynamic self-regulatory processing model”, Psychological Inquiry, Vol. 12 No. 4, pp. 177-196. 
Nelson, M. (1977), The narcissistic condition: A fact of our lives and times, Human Sciences, Oxford.

Paulhus, D. and Williams, K. (2002), "The dark triad of personality: Narcissism, Machiavellianism and Psychopathy", Journal of Research in Personality, Vol. 36 No. 6, pp. 556-563.

Pew Research Center (2007), How young people view their lives, futures and politics: A portrait of "Generation Next", Pew Research Center for the People and the Press, Washington DC.

Pincus AL, Ansell EB, Pimentel CA, Cain NM, Wright AG, and Levy, K.N. (2009), "Initial construction and validation of the Pathological Narcissism Inventory", Psychological Assessment, Vol. 21 No.3, pp. 365-379.

Raskin, R. and Hall, C. (1979), “A narcissistic personality inventory”, Psychological Reports, Vol. 45 No. 2, pp. 590.

Raskin, R. and Terry, H. (1988), "A principal component analysis of the NPI and further evidence of construct validity", Journal of Personality and Social Psychology, Vol. 54 No. 5, pp. 890-902.

Resick, C. J., Whitman, D. S., Weingarden, S. M. and Hiller, N. J. (2009), “The bright side and the dark side of CEO personality: examining core self-evaluations, narcissism, transformational leadership and strategic influence", Journal of Applied Psychology, Vol. 94 No. 6, pp. 1365-1381.

Rhodewalt, F. and Morf, C. (1995), "Self and Interpersonal Correlates of the Narcissistic Personality Inventory: A Review and New Findings", Journal of Research in Personality, Vol. 29 No. 1, pp. 1-23.

Robak, R., Chiffriller, S. and Zappone, M. (2007), “College students' motivations for money and subjective well-being”, Psychological Reports, Vol.100 No 1,pp. 147-156.

Roberts, B., Edmonds, G. and Grijalva, E. (2010), "It is developmental me, not generation me: Developmental changes are more important than generational changes in narcissism commentary on Trzesniewski and Donnellan (2010)", Perspectives on Psychological Science, Vol. 5 No. 1, pp. 97-102.

Rosenthal, S. and Pittinsky, T. (2006), "Narcissistic leadership", The Leadership Quarterly, Vol. 17 No. 6, pp. 617-633.

Sedikides, C. and Campbell, W.K. (2017), "Narcissistic Force Meets Systemic Resistance: The Energy Clash Model”, Perspectives on Psychological Science, Vol. 12 No 3, pp. 400-421.

Sedikides, C., Rudich, E.A., Gregg, A.P., Kumashiro, M. and Rusbult, C. (2004), “Are normal narcissists psychologically healthy? Self-esteem matters", Journal of Personality and Social Psychology, Vol. 87 No. 3, pp. 400-416.

Sotiropoulos, D.A. (2014), "The social situation in Greece under the crisis”, Friedrich Ebert Stiftung, available at http://www.lse.ac.uk/HellenicObservatory/Assets/Documents/Publications/Books/2014-15/Social-Situation-inGreece-2013-Sotiropoulos.pdf (accessed 25 March, 2019). 
Stein, J. (2013), “Millennials: The Me Me Me generation”, Time, 20 May, available at http://time.com/247/millennials-the-me-me-me-generation/ (accessed 10 November 2018).

Svindseth, M. F., Sørebø, Ø., Nøttestad, J. A., Roaldset, J. O., Wallin, J., and Dahl, A. A. (2009), "Psychometric examination and normative data for the Narcissistic Personality Inventory 29 item version", Scandinavian Journal of Psychology, Vol. 50 No.2, pp. 151-159.

Traiser, S. and Eighmy, M. (2011), "Moral development and narcissism of private and public university business students", Journal of Business Ethics, Vol. 99 No. 3, pp. 325-334.

Trzesniewski, K., Donnellan, M. and Robins, R. (2008), "Is generation me really more narcissistic than previous generations?", Journal of Personality, Vol. 76 No. 4, pp. $903-$ 918.

Turnipseed, D. and Cohen, S. (2015), “Academic entitlement and socially aversive personalities: Does the dark triad predict academic entitlement?", Personality and Individual Differences, Vol. 82. pp. 72-75.

Twenge, J. and Campbell, W. (2009), The narcissism epidemic: Living in the age of entitlement, Free Press, New York.

Twenge, J. M., Konrath, S., Foster, J.D., Campbell, W.K., Bushman, B.J. (2008), “Egos inflating over time: a cross temporal meta-analysis of the Narcissistic Personality Inventory", Journal of Personality, Vol. 76 No. 4, pp. 875-902.

Twenge, J. M., Konrath, S., Foster, J.D., Campbell, W.K., Bushman, B.J. (2008b), "Further evidence of an increase in narcissism among college students", Journal of Personality, Vol. 76 No. 4, pp. 919-928.

Wallace, H. M., and Baumeister, R. F. (2002), "The performance of narcissists rises and falls with perceived opportunity for glory", Journal of Personality and Social Psychology, Vol. 82 No. 5, pp. 819-834.

Westerman, J., Bergman, J.Z., Bergman, S.M. and Daly, J. P. (2012), “Are universities creating narcissistic employees? An empirical examination of narcissism in business studies and its implications", Journal of Management Education, Vol. 36 No. 1,pp. 532 .

Westerman, J.W., Whitaker, B.G., Bergman, J.Z., Bergman, S.M., Daly, J.P. (2016), "Faculty narcissism and student outcomes in business higher education: A student faculty fit analysis", The International Journal of Management Education, Vol. 14 No. 2,pp. 63-73.

Wetzel, E., Brown, A., Hill, P.L., Chung, J.M., Robins, R.W., Roberts, B.W. (2017), "The narcissism epidemic is dead; long live the narcissism epidemic", Psychological Science, Vol. 28 No. 12,pp. 1833 - 1847. 
Table 1: Previous studies of narcissism in business education

\begin{tabular}{|c|c|c|c|}
\hline Author(s) & Instrument & Sample & Main Findings \\
\hline Carroll (1987) & $\begin{array}{l}\text { NPI, Thematic } \\
\text { Apperception Test }\end{array}$ & MBA students $(\mathrm{n}=65)$ & $\begin{array}{l}\text { Differences between men and women regarding narcissism. Narcissism has been } \\
\text { found to be positively correlated with the need for power and negatively with the } \\
\text { need for intimacy. }\end{array}$ \\
\hline $\begin{array}{l}\text { Twenge et al., } \\
\quad(2008)\end{array}$ & NPI & $\begin{array}{l}85 \text { samples of American college } \\
\text { students (1980- 2006) }(\mathrm{n}=16475 \\
\text { USA) }\end{array}$ & $\begin{array}{l}\text { Narcissism scores are significantly correlated with year (weighted by sample } \\
\text { size). } \\
\text { Rise of individualistic traits like assertiveness, agency, self-esteem, and } \\
\text { extraversion. }\end{array}$ \\
\hline $\begin{array}{l}\text { Trzesniewski et } \\
\text { al. (2008) }\end{array}$ & NPI & $\begin{array}{l}\text { College students ( } \mathrm{n}=26887, \mathrm{USA}) \\
\qquad 1982-2007\end{array}$ & $\begin{array}{l}\text { No evidence that college students' scores on the Narcissistic Personality } \\
\text { Inventory increased (Univ California Campuses) } \\
\text { Small changes in specific facets of narcissism. }\end{array}$ \\
\hline $\begin{array}{l}\text { Twenge et al., } \\
\quad(2008 b)\end{array}$ & NPI & $\begin{array}{l}7 \text { samples University of California } \\
\qquad(\mathrm{n}=2652 \text {, USA })\end{array}$ & $\begin{array}{c}\text { Corroborate the above findings of Trzesniewski et al. (2008) which can be } \\
\text { justified by cultural and ethnic shifts that took place at the University of } \\
\text { California. } \\
\text { Excluding the California samples, narcissism increased } \\
1988-2006 \text { across } 27 \text { campuses }\end{array}$ \\
\hline \multirow{2}{*}{$\begin{array}{l}\text { Brunell et al., } \\
\quad(2008)\end{array}$} & $\begin{array}{l}\text { Studies 1,2: NPI } \\
\text { Big Five Inventory } \\
\text { Rosenberg Self- } \\
\text { Esteem Inventory }\end{array}$ & $\begin{array}{l}\text { Study 1: introductory psychology } \\
\text { Students }(\mathrm{n}=432) \\
\text { Study 2: introductory psychology } \\
\text { Students }(\mathrm{n}=408)\end{array}$ & $\begin{array}{l}\text { In the first two studies it was found that narcissism is a predictor of leader } \\
\text { emergence and that it is positively correlated with the desire to lead and self- } \\
\text { ratings on leadership. }\end{array}$ \\
\hline & $\begin{array}{l}\text { Study 3: California } \\
\text { Psychological } \\
\text { Inventory- } \\
\text { Narcissism scale }\end{array}$ & $\begin{array}{l}\text { Study 3: managers enrolled } \\
\text { in an executive MBA (EMBA) } \\
\text { program at a large southeastern } \\
\text { university }(2002-2005)(\mathrm{n}=153)\end{array}$ & $\begin{array}{l}\text { In the third study it was shown that students rated highest in narcissism were most } \\
\text { likely to be identified as emerging leaders }\end{array}$ \\
\hline $\begin{array}{l}\text { Brown et.al } \\
\quad(2010)\end{array}$ & $\begin{array}{l}\text { Phares and Erskine } \\
\text { Selfishism Test }\end{array}$ & $\begin{array}{l}\text { Business students at a large } \\
\text { research university }(\mathrm{n}=309)\end{array}$ & $\begin{array}{l}\text { Empathy and narcissism are factors that determine if a student makes an ethical } \\
\text { decision. } \\
\begin{array}{l}\text { Students studying finance exhibited a statistically significant tendency for less } \\
\text { empathy and more narcissism compared to other business students. }\end{array}\end{array}$ \\
\hline $\begin{array}{c}\text { Traiser \& } \\
\text { Eighmy (2011) }\end{array}$ & $\begin{array}{l}\text { Defining Issues } \\
\text { Test version } 2 \\
\text { (DIT-2) \& } \\
\text { NPI }\end{array}$ & $\begin{array}{l}\text { Undergraduate business students } \\
\text { in North Dakota and Minnesota } \\
\qquad(\mathrm{n}=269, \text { USA) }\end{array}$ & $\begin{array}{l}\text { Private college students showed higher NPI scores than public college students } \\
\text { Males were found to be more narcissistic than females } \\
\text { NPI scores increase as family income increases } \\
\text { As age increases, NPI scores decrease } \\
\text { The number of ethics courses that students take does not impact their moral } \\
\text { reasoning or narcissism }\end{array}$ \\
\hline $\begin{array}{c}\text { Menon \& } \\
\text { Sarland (2011) }\end{array}$ & $\begin{array}{c}\text { NPI \& } \\
\text { Machiavellian } \\
\text { Index (Mach 4) }\end{array}$ & $\begin{array}{l}\text { Undergraduate and graduate } \\
\text { students (USA) }\end{array}$ & $\begin{array}{l}\text { Correlation of narcissism and academic entitlement } \\
\text { Narcissism and academic entitlement are predictors of exploitative attitude. } \\
\text { The exploitative attitude is acting as a mediator in the relationship between } \\
\text { narcissism and academic entitlement, and academic dishonesty. }\end{array}$ \\
\hline $\begin{array}{l}\text { Westerman et al., } \\
\quad(2012)\end{array}$ & NPI & $\begin{array}{l}\text { Undergraduate business and } \\
\text { psychology students of an AACSB } \\
\text { state university } \\
(\mathrm{n}=536, \text { USA) }\end{array}$ & $\begin{array}{c}\text { Current college students have higher narcissistic scores than college students of } \\
\text { the past } \\
\text { Business students are more narcissists than their psychology colleagues } \\
\text { Narcissism does not appear to have any significant relationship with class } \\
\text { activities } \\
\text { Narcissistic individuals seem to be more successful in terms of employment, } \\
\text { salary and promotions }\end{array}$ \\
\hline $\begin{array}{l}\text { Mathieu \& St } \\
\text { Jean (2013) }\end{array}$ & NPI -16 & $\begin{array}{l}\text { On line survey; } 1572 \text { students } \\
\text { accepted the invitation, and } 89 \% \\
\text { of them } \\
\text { were enrolled from Universities } \\
\text { across Quebec, Canada. }\end{array}$ & $\begin{array}{l}\text { Student entrepreneurs are more narcissistic than other vocational groups. } \\
\text { Narcissism is positively correlated with general self-efficacy, locus of control and } \\
\text { risk propensity. } \\
\text { Narcissism plays a significant role in explaining entrepreneurial intentions, even } \\
\text { after controlling for self-efficacy, locus of control and risk propensity. }\end{array}$ \\
\hline $\begin{array}{l}\text { Brown et al., } \\
\quad \text { (2013) }\end{array}$ & NPI & $\begin{array}{l}\text { College accounting majors } \\
\qquad(\mathrm{n}=120, \text { USA })\end{array}$ & $\begin{array}{c}\text { Accounting students have a lower level of narcissism in comparison with other } \\
\text { business students and the general population of college students. } \\
\text { There are not significant differences between state and private school students. } \\
\text { There are differences between men and women regarding vanity (women score } \\
\text { higher) and entitlement (men scored higher). } \\
\text { Students who hold leadership positions attain higher NPI scores }\end{array}$ \\
\hline $\begin{array}{l}\text { Bergman et al., } \\
\text { (2013) }\end{array}$ & $\begin{array}{l}\text { NPI } \\
\text { Material Values } \\
\text { Scale } \\
\text { New Ecological } \\
\text { Paradigm Scale }\end{array}$ & $\begin{array}{l}\text { Business students of an AACSB } \\
\text {-accredited business school } \\
\text { ( } \mathrm{n}=405, \text { USA })\end{array}$ & $\begin{array}{l}\text { Strong connection of narcissism and materialism which was significantly related } \\
\text { to lower levels of environmental ethics. This could have negative implications for } \\
\text { societies. } \\
\text { Narcissism has an indirect (no direct) effect on students' environmental ethics. } \\
\text { Narcissism related to materialism and materialism to lower environmental ethics }\end{array}$ \\
\hline $\begin{array}{c}\text { Gkika \& } \\
\text { Sahinidis (2013) }\end{array}$ & NPI & $\begin{array}{l}1449 \text { business students (TEI } \\
\text { Athens, Greece) and their parents }\end{array}$ & $\begin{array}{c}\text { Aging reduces traits of narcissism } \\
\text { Males score higher than female regarding self-absorption, self-admiration, } \\
\text { leadership/authority and superiority/arrogance } \\
\text { Students narcissism level is higher than the one of their parents }\end{array}$ \\
\hline $\begin{array}{l}\text { Turnipseed \& } \\
\text { Cohen (2015) }\end{array}$ & $\begin{array}{l}\text { Dark Triad concise } \\
\text { measure }\end{array}$ & 169 students & $\begin{array}{l}\text { Male students score significantly higher than females on the dark personalities, } \\
\text { and on externalized responsibility. }\end{array}$ \\
\hline $\begin{array}{l}\text { Westerman et } \\
\text { al.,(2016) }\end{array}$ & NPI & $\begin{array}{c}405 \text { undergraduate business } \\
\text { students at a AACSB-accredited } \\
\text { state university - } \\
\text { Southeastern United States }\end{array}$ & 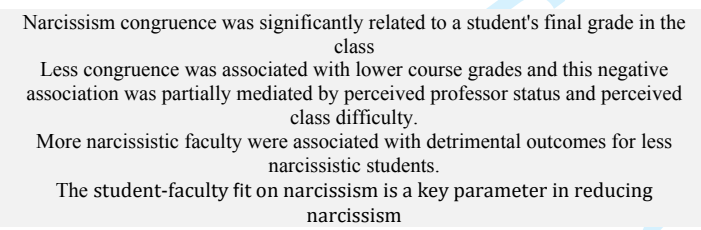 \\
\hline
\end{tabular}


Table 2: Descriptives of NPI and NPI dimensions

\begin{tabular}{|c|c|c|c|c|c|c|c|c|c|}
\hline & & $\bar{z} \frac{\hat{7}}{\mathrm{e}}$ & 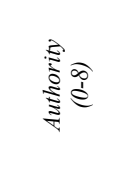 & 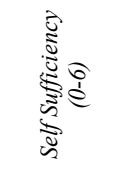 & 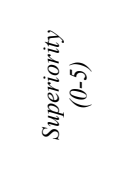 & 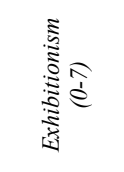 & 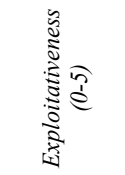 & $\stackrel{\vec{\Xi}}{\overline{0}}$ & 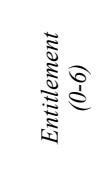 \\
\hline \multirow{2}{*}{ 离 } & Male & $\begin{array}{c}16.3 \\
(\mathrm{SD}=6.58)\end{array}$ & $\begin{array}{c}4.66 \\
(\mathrm{SD}=1.82)\end{array}$ & $\begin{array}{c}1.91 \\
(\mathrm{SD}=1.37)\end{array}$ & $\begin{array}{c}1.98 \\
(\mathrm{SD}=1.33)\end{array}$ & $\begin{array}{c}2.49 \\
(\mathrm{SD}=1.72)\end{array}$ & $\begin{array}{c}1.74 \\
(\mathrm{SD}=1.41)\end{array}$ & $\begin{array}{c}1.07 \\
(\mathrm{SD}=1.06)\end{array}$ & $\begin{array}{c}2.4 \\
(\mathrm{SD}=1.39\end{array}$ \\
\hline & Female & $\begin{array}{c}15.15 \\
(\mathrm{SD}=6.14)\end{array}$ & $\begin{array}{c}3.89 \\
(\mathrm{SD}=1.99)\end{array}$ & $\begin{array}{c}1.51 \\
(\mathrm{SD}=1.3)\end{array}$ & $\begin{array}{c}1.92 \\
(\mathrm{SD}=1.28)\end{array}$ & $\begin{array}{c}2.44 \\
(\mathrm{SD}=1.74)\end{array}$ & $\begin{array}{c}1.73 \\
(\mathrm{SD}=1.37)\end{array}$ & $\begin{array}{c}1.49 \\
(\mathrm{SD}=1.11)\end{array}$ & $\begin{array}{c}2.19 \\
(\mathrm{SD}=1.46\end{array}$ \\
\hline \multirow{4}{*}{ 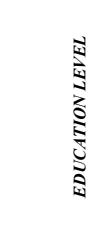 } & UG & $\begin{array}{c}15.10 \\
(\mathrm{SD}=5.97)\end{array}$ & $\begin{array}{c}3.79 \\
(\mathrm{SD}=1.9)\end{array}$ & $\begin{array}{c}1.44 \\
(\mathrm{SD}=1.1)\end{array}$ & $\begin{array}{c}1.9 \\
(\mathrm{SD}=1.26)\end{array}$ & $\begin{array}{c}2.53 \\
(\mathrm{SD}=1.77)\end{array}$ & $\begin{array}{c}1.82 \\
(\mathrm{SD}=1.26)\end{array}$ & $\begin{array}{c}1.35 \\
(\mathrm{SD}=1.1)\end{array}$ & $\begin{array}{c}2.23 \\
(\mathrm{SD}=1.4)\end{array}$ \\
\hline & PG (FT) & $\begin{array}{c}17.01 \\
(\mathrm{SD}=6.99)\end{array}$ & $\begin{array}{c}4.67 \\
(\mathrm{SD}=1.94)\end{array}$ & $\begin{array}{c}1.87 \\
(\mathrm{SD}=1.48)\end{array}$ & $\begin{array}{c}1.95 \\
(\mathrm{SD}=1.36)\end{array}$ & $\begin{array}{c}2.54 \\
(\mathrm{SD}=1.87)\end{array}$ & $\begin{array}{c}1.99 \\
(\mathrm{SD}=1.46)\end{array}$ & $\begin{array}{c}1.49 \\
(\mathrm{SD}=1.24)\end{array}$ & $\begin{array}{c}2.49 \\
(\mathrm{SD}=1.53)\end{array}$ \\
\hline & PG (PT) & $\begin{array}{c}15.26 \\
(\mathrm{SD}=5.97)\end{array}$ & $\begin{array}{c}4.29 \\
(\mathrm{SD}=1.9)\end{array}$ & $\begin{array}{c}1.85 \\
(\mathrm{SD}=1.48)\end{array}$ & $\begin{array}{c}1.95 \\
(\mathrm{SD}=1.34)\end{array}$ & $\begin{array}{c}2.34 \\
(\mathrm{SD}=1.53)\end{array}$ & $\begin{array}{c}1.55 \\
(\mathrm{SD}=1.47)\end{array}$ & $\begin{array}{c}1.15 \\
(\mathrm{SD}=1.02)\end{array}$ & $\begin{array}{c}2.17 \\
(\mathrm{SD}=1.44)\end{array}$ \\
\hline & DOC & $\begin{array}{c}15.44 \\
(\mathrm{SD}=7.18)\end{array}$ & $\begin{array}{c}4.52 \\
(\mathrm{SD}=2.26)\end{array}$ & $\begin{array}{c}1.56 \\
(\mathrm{SD}=1.29)\end{array}$ & $\begin{array}{c}2.08 \\
(\mathrm{SD}=1.26)\end{array}$ & $\begin{array}{c}2.4 \\
(\mathrm{SD}=1.94)\end{array}$ & $\begin{array}{c}1.32 \\
(\mathrm{SD}=1.25)\end{array}$ & $\begin{array}{c}1.28 \\
(\mathrm{SD}=1.06)\end{array}$ & $\begin{array}{c}2.32 \\
(\mathrm{SD}=1.31)\end{array}$ \\
\hline
\end{tabular}


Table 3: Hypotheses Tests

\begin{tabular}{|c|c|c|c|c|c|c|}
\hline & $\begin{array}{c}H 1 \\
(\operatorname{sex})\end{array}$ & $\begin{array}{c}H 2 \\
\text { (level of study) }\end{array}$ & $\begin{array}{c}\text { H3 } \\
\text { (business } \\
\text { experience) }\end{array}$ & $\begin{array}{c}\mathrm{H} 4 \\
\text { (career } \\
\text { objectives) }\end{array}$ & $\begin{array}{c}\text { H5 } \\
\text { (individual } \\
\text { income) }\end{array}$ & $\begin{array}{c}\text { H6 } \\
\text { (family } \\
\text { income) }\end{array}$ \\
\hline \multirow{8}{*}{$\begin{array}{c}\text { NPI } \\
\text { Authority } \\
\text { Self } \\
\text { Sufficiency } \\
\text { Superiority } \\
\text { Exhibitionism } \\
\text { Exploitativene } \\
\text { ss } \\
\text { Vanity } \\
\text { Entitlement }\end{array}$} & Tenable & Tenable & Tenable & Tenable & Tenable & Non tenable \\
\hline & Non tenable & Non tenable & Non tenable & Tenable & Tenable & Non tenable \\
\hline & Non tenable & Tenable & Non tenable & Tenable & Tenable & Tenable \\
\hline & Tenable & Tenable & Tenable & Non tenable & Tenable & Non tenable \\
\hline & Tenable & Tenable & Tenable & Tenable & Tenable & Non tenable \\
\hline & Tenable & Non tenable & Non tenable & Tenable & Tenable & Tenable \\
\hline & Non tenable & Tenable & Non tenable & Tenable & Non tenable & Tenable \\
\hline & Tenable & Tenable & Tenable & Tenable & Tenable & Non tenable \\
\hline
\end{tabular}

Table 4: Kruskal Wallis Test (NPI \& NPI Dimensions_Career Plans)

\begin{tabular}{|c|c|c|c|c|c|c|c|c|}
\hline & 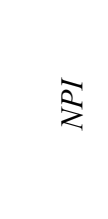 & 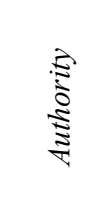 & 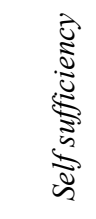 & 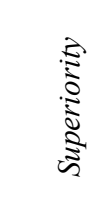 & 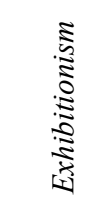 & 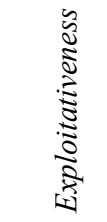 & $\stackrel{\vec{\Xi}}{\stackrel{\Xi}{\Xi}}$ & 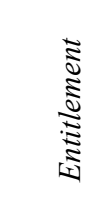 \\
\hline$X^{2}(9)$ & 14,472 & 7,631 & 8,873 & 17,018 & 4,079 & 13,628 & 14,489 & 12,038 \\
\hline$p$ & 0,106 & 0,572 & 0,449 & 0,048 & 0,906 & 0,136 & 0,106 & 0,211 \\
\hline
\end{tabular}

Table 5: Mann Whitney U results (Vanity_Personal Income)

\begin{tabular}{|c|c|c|c|c|}
\hline Mann Whitney $U$ & $Z$ & $p$ & Cohen's (r) & $\begin{array}{l}\text { Personal Income } \\
\text { Groups (in EUR) }\end{array}$ \\
\hline 788.00 & -2.575 & 0.010 & $\begin{array}{c}0.23 \\
\text { Small to } \\
\text { moderate }\end{array}$ & $\begin{array}{c}0 ; \\
\text { over } 30000\end{array}$ \\
\hline 658.00 & -2.376 & 0.017 & $\begin{array}{c}0.25 \\
\text { Small to } \\
\text { moderate }\end{array}$ & $\begin{array}{l}5001-10000 \\
10001-20000\end{array}$ \\
\hline 185.00 & -2.392 & 0.001 & $\begin{array}{c}0.45 \\
\text { Almost large }\end{array}$ & $\begin{array}{c}5001-10000 \\
\text { over } 30000\end{array}$ \\
\hline 224.00 & -2.060 & 0.039 & $\begin{array}{c}0.29 \\
\text { Almost moderate }\end{array}$ & $\begin{array}{l}20001-30000 \\
\text { over } 30000\end{array}$ \\
\hline
\end{tabular}


Table 6: Mann Whitney U results (NPI Family Income)

\begin{tabular}{|c|c|c|c|c|}
\hline Mann Whitney $U$ & $Z$ & $p$ & Cohen`s (r) & $\begin{array}{l}\text { Family Income } \\
\text { Groups (in EUR) }\end{array}$ \\
\hline 1348.5 & -2.836 & 0.005 & $\begin{array}{c}0.25 \\
\text { Small to } \\
\text { moderate }\end{array}$ & $\begin{array}{l}\text { Up to } 20000 \\
40001-70000\end{array}$ \\
\hline 217 & -2.789 & 0.005 & $\begin{array}{c}0.29 \\
\text { almost moderate }\end{array}$ & $\begin{array}{l}\text { Up to } 20000 \\
70001-90000\end{array}$ \\
\hline 2170 & -2.249 & 0.025 & $\begin{array}{c}0.17 \\
\text { Small to } \\
\text { moderate }\end{array}$ & $\begin{array}{l}20001-40000 \\
40001-70000\end{array}$ \\
\hline 342.5 & -2.613 & 0.009 & $\begin{array}{l}0.23 \\
\text { Small to } \\
\text { moderate }\end{array}$ & $\begin{array}{c}20001-40000 \\
70001-90000\end{array}$ \\
\hline
\end{tabular}


Table 7: Mann Whitney U results (NPI Dimensions_Family Income)

\begin{tabular}{|c|c|c|c|c|c|}
\hline & $\begin{array}{c}\text { Mann } \\
\text { Whitney } U\end{array}$ & $Z$ & $p$ & Cohen's (r) & $\begin{array}{c}\text { Family Income } \\
\text { Groups (in } \\
\text { EUR) }\end{array}$ \\
\hline \multirow{2}{*}{ Authority } & 1301 & -3.102 & 0.002 & $\begin{array}{c}0.27 \\
\text { Small to } \\
\text { moderate }\end{array}$ & $\begin{array}{l}\text { Up to } 20000 \\
40001-70000\end{array}$ \\
\hline & & -2.652 & 0.008 & $\begin{array}{c}0.28 \\
\text { Small to } \\
\text { moderate }\end{array}$ & $\begin{array}{l}\text { Up to } 20000 \\
70001-90000\end{array}$ \\
\hline \multirow{3}{*}{ Superiority } & 246 & -2.499 & 0.012 & $\begin{array}{c}0.26 \\
\text { Small to } \\
\text { moderate }\end{array}$ & $\begin{array}{l}\text { Up to } 20000 \\
70001-90000\end{array}$ \\
\hline & 321 & -2.87 & 0.004 & $\begin{array}{c}0.25 \\
\text { Small to } \\
\text { moderate }\end{array}$ & $\begin{array}{c}20001-40000 \\
70001-90000\end{array}$ \\
\hline & 153.5 & -2.125 & 0.034 & $\begin{array}{c}0.28 \\
\text { Small to } \\
\text { moderate }\end{array}$ & $\begin{array}{c}40001-70000 \\
70001-90000\end{array}$ \\
\hline \multirow{3}{*}{ Exhibitionism } & 1435.5 & -2.446 & 0.014 & $\begin{array}{c}0.22 \\
\text { Small to } \\
\text { moderate }\end{array}$ & $\begin{array}{l}\text { Up to } 20000 \\
40001-70000\end{array}$ \\
\hline & 240.5 & -2.549 & 0.011 & $\begin{array}{c}0.26 \\
\text { Small to } \\
\text { moderate }\end{array}$ & $\begin{array}{l}\text { Up to } 20000 \\
70001-90000\end{array}$ \\
\hline & 418 & -2.012 & 0.044 & $\begin{array}{c}0.18 \\
\text { Small to } \\
\text { moderate }\end{array}$ & $\begin{array}{c}20001-40000 \\
70001-90000\end{array}$ \\
\hline \multirow{4}{*}{ Entitlement } & 1318.5 & -3.039 & 0.002 & $\begin{array}{c}0.27 \\
\text { Small to } \\
\text { moderate }\end{array}$ & $\begin{array}{l}\text { Up to } 20000 \\
40001-70000\end{array}$ \\
\hline & 241.5 & -2.540 & 0.011 & $\begin{array}{c}0.26 \\
\text { Small to } \\
\text { moderate }\end{array}$ & $\begin{array}{l}\text { Up to } 20000 \\
70001-90000\end{array}$ \\
\hline & 2154 & -2.356 & 0.018 & $\begin{array}{c}0.18 \\
\text { Small to } \\
\text { moderate }\end{array}$ & $\begin{array}{c}20001-40000 \\
40001-70000\end{array}$ \\
\hline & 402.5 & -2.155 & 0.031 & $\begin{array}{c}0.19 \\
\text { Small to } \\
\text { moderate }\end{array}$ & $\begin{array}{c}20001-40000 \\
70001-90000\end{array}$ \\
\hline
\end{tabular}

